\title{
To the Issue of Mikhail Shepkin's Artistic Method
}

\author{
Renat Mukhaev \\ Russian State Specialized Arts Academy \\ Moscow, Russia \\ e-mail: renamu@yandex.ru
}

\begin{abstract}
This article is dedicated to the creative method of Mikhail Shepkin, one of the great Russian actor, the reformer of performing arts. There is a retrospective view given on this outstanding person who exerted radical influence on the process of development of Russian drama theatre in the context of modern stage performing and its problems.
\end{abstract}

Keywords-theatre; Schepkin; Mochalov; Rachel;
Ostrovsky; Chekhov; Stanislavsky

\section{THE HISTORY OF RUSSIAN THEATRE}

In the history of the Russian theater a figure of Mikhail Shepkin plays a special role among the great actors, who ever played on the Russian stage. For more than half a century Shepkin was working in the Russian theater. Schepkin's art is not marked with any mystery fleur. His creative approach is marked with clear moral standards and complete scenic images incorporation. He played an important role in that historic moment when the Russian drama school faced a cross-road.

There were two possible ways for the Russian national drama school to go: one led to the past, to the trivial acting methods, the other led to natural acting and «simplicity» of acting, which were foreign to most of the actors before Shepkin.

«A whole generation's teacher» - an influence of the intuitive genius of P.S. Mochalov on the first Russian Revolutionary democrats was characterized in such a way by the famous Russian literature critic Vissarion Belinsky.

The great critic's definition cannot be applied to Shepkin`s art, whose contribution as an actor and a teacher is far beyond one generation's chronological frames. His civil position could be called an evolutionary one, but not the revolutionary. «»Spread the thought, but not water with blood», - Shepkin wrote to the London recluse Alexander Herzen.

B. Alpers in his book «Mochalov`s and Shepkin`s Theatre» justly remarked: «Shepkin is not only the past, but also the present time» $[1,266]$. In other words, art and the dispensations of the great Russian actor are still actual.

Shepkin's first theatre appearance took place in 1805 on a provincial theater stage. It was a time of the last outbreak of the Classicism theatre. Two years earlier than Shepkin another famous Russian actress started her career on St. Petersburg stage. It was the great Russian tragic actress Catherine Semyonova.

\section{RUSSIAN THEATRE AROUND THE WORLD}

Due to some reasons Shepkin didn't see this legendary competition between the Russian and the French schools representatives in the face of Semyonova and another famous tragic actress George. This competition lasted for several days in Arbat Theatre, where theatric community of Moscow followed this performance with a breath taken. The standing stalls were full and people in it «were stuck like herring in a fish-barrel» $[6,7]$. Catherine Semyonova was the winner, who overcame Cornell's, Racine's and Voltaire's co-citizen. It was a legendary triumph of the Russian performance art in the tragic genre. At that time the Classicism art was percepted as a reflection of public life, but primarily using antique forms of the tragic style. It's influence reflected on the Moscow's aristocracy.

In two decades Classicism became far away from reality art. In the 1820's, when Shepkin comes to the Maly Theatre, the social aspect outweighs the aesthetic one away from stage. Being away from the capital cities Shepkin could judge about the Classicism only by the artificial acting of provincial actors. Only some years later he saw on stage a great Classic performer - Eliza Rachel. She brought confusion to his soul. Shepkin realized that he won't be able to take the actress's advice and to play a role of Garpagon «forty times away» He didn't have the «training, which Rachel possessed, who was able to play a complex tragic role several times away. It was impossible even for Shepkin, who was fantastically hard-working and a most thorough actor in his profession.

The complexity was in another method of acting. Rachel belonged to a different theater and for her a superficially fine technique was important. Shepkin believed in living his role through, while formal methods of acting meant less for him since his young years. Using terminology, in the first case an actor had to "falsificate» and in the second one «to become» a character, which demanded much more energy and power. Yet, learning the acting secrets took Shepkin the same way as Rachel - it was the recognizing of some characteristic features of the character, but taking it from the content, which Rachel was lacking.

\section{COMPETITION}

He could never compete with the French actress; Semenova never did it, who fought the French George actress with her own arms. A Russian actor's power meant weakness for a French actress. Still, Rachel clearly taught 
Shepkin that «learning is important and an actor should study how to say a great speech, not letting it to a case or nature» $[4,228]$ In a recommendation to his student A. I. Schubert remarked: «Study it (art - remark by the present author) as a science, not a fake» $[4,200]$ By the «fake he meant a false conventionalism, which was typical not only for the provincial, but also for the capital theaters.

One of the Maly Theatre's actors, who was contemporary to Shepkin, described in general the most typical methods of such conventional acting. In tragedies and dramas it looked like this: the protagonist with curly hair walked like a crane along the stage, saying his text in a melodic tone, and when moving his leg had to tiptoe.

An evil man appeared in a red-haired wig, with his head lowered, wild eyes and an especially harsh voice. The wild weepings of the first and the second expressed the inner escalation. In their pathetic dialogues they both took very high notes with such modulations that it made your blood freeze.

The leading actress was in no way better, which was obviously doomed to die. But how? It was the main secret. During several acts with special exclamations the actress hinted to the tragic ending. In the final scene she would appear in a hood with loose hair, with a lace hankerchief in a hand.

At that time it was called «to show a tragedy» «The strange thing is», - a witness wrote, - "that in spite of the weight of the external and some other methods, they could still enter a role indeed and as if felt and suffered» $[5,135-$ 136].

An important meaning for Shepkin about an event coming to the Maly Theatre was that, being already a formed actor, an adult man and a father of a family, neither the routine of the stage prejudices, nor the behind the stage intrigues could influence him. Moscow had already heard of him as a great actor. Such advertising could be given only to a very special actor. So it is not surprising that Shepkin charmed Moscow audiences from the very beginning, which still did not realize the discovery of the new era on the Russian stage - the era of overwhelming of the «passions truth and true feeling loving» over the conventions.

Shepkin owes his growth to an amateur actor Prince Meshersky, who pointed a young actor a way to the stage art. «Everything that resulted in me, - Shepkin wrote later, «I owe to this person, he was the first to plant the right idea of art in me and showed me that art is as high as it is close to nature» $[4,105]$.

From his «Notes» we learn that at first Meshersky`s performance manner was treated like poor acting. Being captured by the false pathos and extreme declamation, Shepkin realized the advantage of the «simplicity» and natural stage behavior, which meant the future. « He is not acting, he is living», — recalled Shepkin Meshersky`s acting. «How many phrases do I have in my memory, which were said easily but passionately». [4, 103]. "Simplicity» and «passion» combined to a limit in the art of a great actor, pointing him out of the performer's mass, which mainly has the stamps of Dmitrievsky`s old school. Yes, we cannot say that Shepkin had no relationship to the old theater with its conventional methods.

\section{IMPROVEMENT}

In Sergey Aksakov`s opinion, he «could never completely get rid of this artificiality, which was heard in his most natural acting» According to A. Grigoriev, «Shepkin, in spite of some amazing features of his acting, as if spoke something different to the audience» [4, 47]. I.V. Samarin told that his teacher had a lot of conventions in his methods, inherited from the old theater [4, p.308]. A composer and a music critic A.N. Serov was more opinionated - he was a great fan of P.M. Sadovsky's art. He found Shepkin`s acting «too mastered, with more or less warts» [4, 127].

Indeed, Shepkin did not have a choice between the old some other acting school. He was taught on theatre examples, which he knew well. Having acquired all the best, he became the main link between the Russian stage of the past and the future. His historic mission allowed him to «create truth on the Russian stage» and, according to Herzen, «to become the first non-theatre in the theatre».

D. Talnikov in his book «Shepkin`s system» explains this «non-theatricality» as the actor's ability to incorporate stage images of conditional-realistic performance [9, 49-50]. In such a case, Shepkin cannot be considered the first in Russian theatre history «non-theatric» actor, since he had some predecessors. For example, such actors as V.P. Pomerantsev, A.M. Krutitsky, partly A.S. Yakovlev and Ya.E Shusherin in Kotsebu's dramas, Ch. F. Rachmanova, who was playing comical old ladies for 40 years. The best definition of Shepkin's «non-theatrality» is provided by Belinsky, who considered that Shepkin was «an actor for elite audience, capable of appraising all the shades of the truly artistic acting».

P. Mochalov may also be called an elite audience's actor. His performance never possessed stability. In order to appreciate his really artistic acting, the audience had to follow Mochalov with great attention, in order not to lose any of his genial «dramatic notes». An outstanding Russian dramatist and theater activist A.A. Shahovskoy briefly characterized the strong and weak points in Mochalov`s acting. «If he matches — it's a miracle. If he does not — it's a trash».

Shepkin's high and stable performance was accepted with warmth and love by Moscow, St. Petersburg and Kazan audiences. His "originality» meant first of all a deeply professional attitude to his business, which lacked many performers, who hoped to impress with their appearance or a special gift. Enthusiastic labour in the process of image creations together with, sacred for him, stage incorporations predetermined Shepkin`s importance as a great actor. On this ground his famous slogan of theatre labour appeared: «Make sacred magic or get out».

Among all the variety of Shepkin's roles the roles of Famusov and the City Policeman are the real masterpieces. These roles were widely mentioned in the XIXth and XXth 
centuries. We have nothing to add to those critical articles. Yet, Shepkin's main roles seem to be under-covered. From the actor's letters it becomes obvious that all his roles were extremely difficult and were mastered for one year to another.

\section{THE OPINIONS OF OTHERS}

Shepkin's Famusov acting lacks of gentry to make his acting perfect» - resumed Belinsky [2,p.333] The actor himself showed that there was just one step from from a great actor to a miserable one.

Shepkin`s Famusov or the Policeman was judged by the same roles actor I.I. Sosnitsky — St. Petersburg analogue of the great Moscow actor. It was considered that Sosnitsky`s Famusov looked more like an important aristocrat and many people preferred his interpretation as the best copy of a Moscow aristocrat of 1820's.

But the thing is that the censure allowed the staging of the comedy only when Griboyedov's Moscow became a memory. "Woe from Wit» is an old time picture, a sad anachronism», - Alexander Pushkin wrote at the beginning of 1830's. "You won't meet Famusov, who is «happy to meet anyone», nor Tatiana Yourievna, who «makes ball parties as rich as possible», Chlestov is in grave. Repetilov is in a village. Poor Moscow!» [7, 247]. Shepkin was living in Moscow and could not help seeing its changing image. He considered Famusov an important Moscow official of 1830 's and in this role he was reminiscent of an ugly official of Nicolas I's time.

Reproaches of «lack of gentry of a real kind» suffered the other generations of performers, including a great Russian actor V.N. Davydov [3, .50, 74]. Half a century later after the performance of the first night of the «Woe from Wit» an actor of the new generation represented Famusov not as an aristocrat, but as a serving military man. An aristocrat, in his opinion, would not fawn to Skalozub, admire Maxim Petrovich or crouch at Chlestova.

Shepkin`s Famusov`s interpretation was subjected to the main theme of his art - the topic of a «small man», which in reality was not only a common man. The same topic sounded in his Policeman's interpretation, who suddenly becomes «small», shivered worth fear and prayed: «Pray, don't harm! My wife, my children...». And when he learned what «an icicle he mistook for an important man», returned to his Policeman's image. Thus an actor showed that there was only one step from great to small acting.

Belinsky called Shepkin a «true priest of the stage art, who realizes that an actor should not be exceptionally tragic, nor exceptionally comic one, but that his real meaning is to show characters». [2, 333].

But to represent characters, as Sostnitsky used to do, and to create complete, socially important images, as Shepkin used to do is not the same. Every particular character with his temperament, gestures, speech and specifics, as a rule, reveals details. Griboyedov in his comedy wanted to show not only a collision of particular characters, but also a collision of ideas of the «past century and the present time» and to satire not the type of a Moscow aristocrat, but a phenomenon of 1920-30's.

Nevertheless, a deeply rooted tradition demanded from Famusov's role performers first of all a character and the truthful features representation. Following this way, an accident happened to the great actor. In one of his performances Shepkin so deeply «felt the skin» of Famusov that unwillingly satirized Tchatsky during his reading of the revealing monologue in the final scene. With every word, pronounced by Tchatsky, Shepkin-Famusov was more and more impressed in his insanity. Looking at Tchatsky, Famusov's smile grew into laughter, contagious on the audience, which immediately started to laugh at Tchatsky`s argumentation. «I immediately felt, — confessed Shepkin», - «that it was a mistake from my side and that I had to be cautious with a feeling» [4, 223-224].

Having experienced a spiritual sensation of the «true» Famusov, an actor actually deactivated Tchatsky`s position, remarked by Pushkin: "Everything that Tchatsky says is very clever. But who does he tell it to?» $[7,138]$. Shepkin proved it in his own experience that a desire of naturalism may object nature and harm his stage position. He realized that life and art are not equal to each other, but are closely connected and an artistic success strongly depends on an ideal combination of convention and nature.

A Russian priest Pavel Florensky offered an interesting motivation on the example of Russian icon-painting showing a mistake of the naturalism approach in art. «A viewer definitely sees a great artistic advantage in one of the icons, which breaks the perspective completely, while more correct icons seem to be cold, lifeless and lacking the reality of the depiction» $[4,48]$.

\section{SHEPKIN'S INFLUENCE}

Shepkin`s «back perspective», who used to say «a kind of different for the audience», allowed lyricism and remained «a bit himself» on stage, distinguished from a creative method of P.M. Sadovsky`s «linear perspective», whose mask would not allow «a needle, without touching a living body» $[4,48]$.

Shepkin in his acting art moved towards the principle of «golden middle» by way of learning of two extremes, without getting to a temptation of conventional theatre and realistic theatre, which was far from life. «No matter how true is the feeling, - stresses Shepkin, — «but if has overcome the borders of a general idea, there's no harmony, which is a common law for art in general». [4, 223]

He did not accept A.N. Ostrovsky`s early drama, which didn't reflect the principles of the «educated» realism, thanks to which, in Belinsky's opinion, Shepkin`s Policeman «didn't help the author, but rivaled him». [2, vol. $2,528]$. The actor was looking for the positive features in the negative characters, warming them with his soul.

Shepkin lived a long life, full of bright events and, in spite of his rich experience, could only guess the way Russian theatre would follow. He would probably not accept its many innovations, which took place 50 years after the 
death of the actor. Probably Shepkin would also reject Anton Chekhov`s drama, like A.P. Lensky and would advise the famous writer not to write at all.

Konstantin Stanislavsky, one of the creators of Moscow Art Theatre, who followed, he thought, Shepkin`s main idea «to take examples from life and from nature». He used to write: «Shepkin, Chekhov and our theatre joined together in our general wish of artistic simplicity and to the stage truth. Casting the theatre out of the theatre, Chekhov never considered its conventionalism. He preferred to have them less, not more. He depicted scenes from life and not pieces for the theatre». [8, vol. 5, book 1,141$]$.

\section{CONCLUSION}

It is hardly possible that Shepkin together with Chekhov and Stanislavsky would «cast out the theatre form theatre». He would never accept Stanislavsky`s slogan: «I hate theatre in the theatre» [8, vol. 5 , book. 1,387$]$. It would be the same as Shepkin saying "I hate God in God".

The preference of some principles for the sake of the others and also opposition of the art to reality can't lead to harmony, which is a "general law for every art». This is the main meaning of the importance of the great Russian actor Mikhail Shepkin.

\section{REFERENCES}

[1] Alpers B.V. Mochalov`s and Shepkin`s theatre. Moscow, 1979, p.266.

[2] Belinsky V.G. Complete Works. 13 volumes. Moscow, 1953-1959.

[3] Davydov V.N. A Story of the Past. Moscow-Leningrad, 1962.

[4] Mikhail Shepkin. Life and Work. 2 volumes. Moscow, 1984.

[5] P.R. The Notes of an Old Actor. Russian Old Time. 1905, Jan.

[6] Polevoy N.A. My Recollections of the Russian Theatre and Russian Drama. Repertoire of the Russian Theatre. 1840, \#2.

[7] Pushkin A.S. Complete works. 17 vols. Moscow, 1996, vol. 11.

[8] Stanislavsky K.S. Complete works, 9 vols. Moscow, 1998-2000.

[9] Talnikov D.L. Shepkin`s System. Moscow-Leningrad, 1939.

[10] Florensky P.A. Back perspective. At the Watershed of Thought». Moscow, 1990, vol. 2 